\title{
韓国における環境規制の強化と紙パルプ産業の対応*
}

\section{Tougher Environment Regulation and Control Practice of Pulping Industry in Korea}

\author{
H. -J. Peter Cho \\ Kookmin University, Korea
}

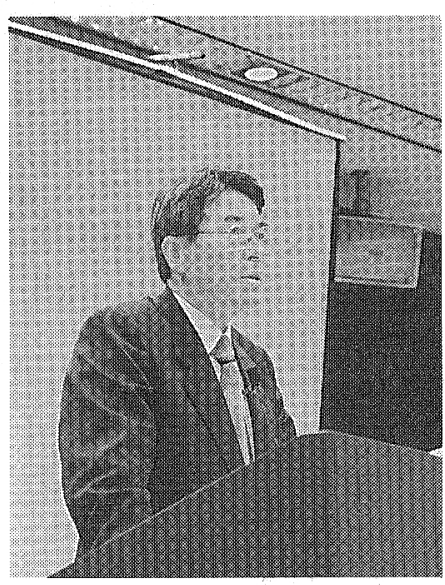

Over the past three decades, the pulp and paper industry has been one of the fastest growing industries of Korea. The country's paper and paperboard consumption has grown at a rate of $14 \%$ per year from 0.05 million $\mathrm{M} / \mathrm{T}$. in 1960 s to $4.52 \mathrm{million} \mathrm{M} / \mathrm{T}$ in $1990 \mathrm{~s}$, which is greater than the growth rate of the general economy of the country.

With the limited potential of its own resources, the pulp and paper industry is heavily dependent upon the fiber resources of foreign, countries. The lack of fiber has led to an imbalance in the development of pulp and paper industry-few pulp mills and many paper mills. As a result, most paper mills rely heavily on imported pulp and wastepaper. This poor resource endowment has led the paper industry to adopt a technology which uses a high ratio of wastepaper upto $55 \%$.

(quoted from the original paper)

\section{(はじめに）}

韓国の紙パルプ産業は，過去 30 年以上にわたつて 韓国で最も成長の著しい産業の 1 つであった。韓国の 紙・板紙消費量は年率 $14 \%$ で增加し，1960 年代には 5 万 $\mathrm{M} / \mathrm{T}$ であったが，1990 年代には 452 万 M/Tに 達した。これは韓国経済全般の成長をしのぐ勢いであ る。

資源がそしいため，紙パルプ産業は繊維原料の多く を海外に依存している。繊維原料不足が原因となって, 紙パルプ産業は不均衡な成長を遂げ，少数のパルプ工 場と多数の抄紙工場が存在する結果となった。大部分 の抄紙工場は原料のパルプや古紙を専ら海外に頼って いる。このような脆弱な資源供給能力の下で, 製紙産

*(翻訳) 株式会社日本紙パルプ研究所 可知 省吾
業は古紙を最大 $55 \%$ まで使用する技術を適用するに 至っている。

\section{1. 環 境規制}

1996 年 8 月 12 日, 韓国政府は 1991 年 2 月 2 日に 制定された水質浄化法（Clean Water Act）の修正 法を施行した。これは 6 年間で 8 度目の修正であり, 規制は以前より一段と厳しいものとなった。

紙パルプ産業は長年にわたって多大な努力を払い, 環境規制に良く適合して来な。しかし，この修正法は 排水問題への包括的な対応だけでなく，今日極めて重 要ないくつかの事項を規制に加えることも目的として いる。

現在, 紙パルプ産業が使用している用水の量は $623,000 \mathrm{~m}^{3} /$ 日と推定されているが，その排水の約 $35 \%$ は BOD が $30 \mathrm{ppm}$ 以上であり，排水の $55.2 \%$ は 
COD が 40 ppm 以上である。

1995 年には, 排水量は $401,196 \mathrm{~m}^{3} /$ 日で，その $140,270 \mathrm{~m}^{3}$ は BOD が $30 \mathrm{ppm}$ 以上, $221,613 \mathrm{~m}^{3}$ は COD が $40 \mathrm{ppm}$ 以上という結果となった。 SS はかな り良い状況で，401,196 $\mathrm{m}^{3}$ の排水の僅かに $14 \%$, $56,539 \mathrm{~m}^{3}$ の排水が $30 \mathrm{mg} / \mathrm{l}$ 以上の SS であった。用 水の $35.6 \%$ リサイクルされていた。

最近まで産業界は環境問題に対してあまり熱心では なかったが, 国民の関心が高まり, 政府による環境污 染防止のための規制が強まると共に, 産業界も迅速か つ誠実にこのような変化に対応せざるを得なくなって 来な。しかし一方で，そのための経済的な負担も重く なっている。

\section{2. 紙パルプ産業の対応}

1996 年の修正法に適応するためには, 韓国内の 112 の紙パルプ】場に対して 1998 年までに 990 億 7,300 万ウオンが必要と見込まれている。非常に莫大な額で あり，準備期間も不十分である。

紙パルプ産業は昨年 168 億 1,700 万ウオンを投入し, 5 ヶ年計画の最終年である 2000 年までには 1,463 億 7,300 万ウオンの投資が見込まれている。その計画は 次の通りである。

First Stage (1996-1998)

Unit : Million Won

\begin{tabular}{|c|c|c|c|c|}
\hline Year & 1996 & 1997 & 1998 & Total \\
\hline Investment & 16,817 & 57,633 & 24,623 & 99,073 \\
\hline
\end{tabular}

Second Stage (1999-2000)

Unit : Million Won

\begin{tabular}{|c|c|c|c|}
\hline Year & 1999 & 2000 & Total \\
\hline Investment & 18,900 & 28,400 & 47,300 \\
\hline
\end{tabular}

長期計画の最終年である 2000 年までに達成すべき 数值目標は, BOD が 20 ppm, COD が 40 ppm, SS が $20 \mathrm{ppm}$ と設定されている。用水の再使用率は次の ような計画に従って改善することとなっている。

\begin{tabular}{|c|c|c|c|c|}
\hline Year & 1998 & 2000 & 2005 & 2010 \\
\hline Reuse Rate (\%) & 43.0 & 45.0 & 60.0 & 70.0 \\
\hline
\end{tabular}

このように，多くの工場で排水量が大幅に削減され ると, 次には排水中の污染物質がより大きな関心事と なって来るであろう。

政府による規制がだんだん厳しくなるに従って，今 後は環境問題に対する圧力も增大し, 紙パルプ産業は 投資に対する姿勢を転換し，経済的な環境污染防止計 画に取り組まざるを得なくなるであろう。

\section{文献}

1) Korea Paper Manufacturer's Association: Paper \& paperboard Statistics Year-Book, 1996.

2) Korea Paper Mannfacturer's Association : Pulp \& Wastepaper Statistics Year Book, 1996.

3) Dept. of Environment, Korea, Pollution Protection Law \& Regulation, 1996.

4) Y.C. Yonn and H.J. Peter Cho.: The prospects of Korean Pulp \& Paper Industry. Internation symposium, Seoul, Korea. p 89-98, 1992.

5) L. Coottschin and H.J. Putz. : Tappi J. Vol.77, p 67-72, 1994. 